\title{
Innovators, Esq.: Training the Next Generation of Lawyer Social Entrepreneurs
}

Stephanie Dangel

Michael J. Madison

March 21, 2014

University of Pittsburgh Innovation Practice Institute White Paper No. 2015-02

University of Pittsburgh Legal Studies Research Paper No. 2015-21

Available at:

http://ssrn.com/abstract=2620307

UNIVERSITY OF PITTSBURGH

I N N O V A T I O N

PRACTICE INSTITUTE

\begin{tabular}{llllllllllllll}
$S$ & $C$ & $H$ & $O$ & $O$ & L & $O$ & $F$ & L & $A$ & W \\
\hline
\end{tabular}

PITT LAW

UNIVERSITY OF PITTSBURGH 


\title{
INNOVATORS, ESQ.: TRAINING THE NEXT GENERATION OF LAWYER SOCIAL ENTREPRENEURS
}

\author{
Stephanie Dangel $^{*}$ and Michael J. Madison ${ }^{* *}$
}

\section{INTRODUCTION}

To survive in today's legal marketplace, all law school graduates must be entrepreneurial: they must be enterprising, opportunistic, and willing to take risks in the hope of reward, just like entrepreneurs. ${ }^{1}$ Yet traditional legal education tends to produce lawyers who are "strange bedfellows" with entrepreneurs. Although many law school programs now train law students to represent entrepreneurs and to be entrepreneurial in law-related careers, few (if any) law schools have programs that train their graduates to be entrepreneurs in non-legal careers. While a legal education may not be the best training for business entrepreneurs, we argue that law schools can and should be training the next generation of social entrepreneurs, i.e., "entrepreneurs who serve the whole of society with solutions that are sustainable, fair and sufficient."

We begin by examining both the tension between entrepreneurs and traditionally-trained lawyers and the innovative programs at many law schools that ameliorate that tension, including the programs offered by our Innovation Practice Institute (IPI) at the University of Pittsburgh School of Law ("Pitt Law"). These programs focus on training law students to represent entrepreneurs ("entrepreneurs' lawyers") and to be entrepreneurial in law-related careers

\footnotetext{
* Executive Director of the Innovation Practice Institute (IPI) at the University of Pittsburgh School of Law (Pitt Law). Email: sad111@pitt.edu. The IPI trains law students to represent innovators and entrepreneurs and to be innovators and entrepreneurs. For a full description of the IPI, see http://innovation-practice.org. Prior to joining the IPI, Stephanie Dangel clerked in New York and Washington, D.C. and worked as a lawyer and social entrepreneur in Pittsburgh.

** Professor of Law and Faculty Director of the Innovation Practice Institute at the University of Pittsburgh School of Law. Email: michael.j.madison@gmail.com. Prior to becoming a law professor, Professor Madison practiced law in Silicon Valley and San Francisco. The authors wish to thank former IPI Executive Directors Max Miller and Justine Kasznica Thornton for their leadership in establishing the IPI and initiating its programs and partnerships; Pitt Law graduates Melinda (Mindy) Cooper and M. Elizabeth Boehm Jorge for research assistance; and Pitt Law Dean William M. Carter, Jr., the Heinz Endowments, Charles J. Queenan, Jr., K\&L Gates and Reed Smith for their support of the IPI.

${ }^{1}$ For more on the role of entrepreneurial thinking and behavior in the context of the modern legal profession and legal education, see David Bennett, The New Normal and the Challenge for Legal Education, Silicon Flatirons Roundtable Series on Entrepreneurship, InNovation, and PuBliC POLICY (April 2004), available at http://www.siliconflatirons.org/documents/publications/report/201404NewNormalReport.pdf; Michael J. Madison, Visions of the Future of (Legal) Education, U. of PitTsburgh Legal StUdies Research PAPer No. 2014-13 (Mar. 20, 2014), available at http://ssrn.com/abstract=2412238. For a review of entrepreneurship generally that links it to economic prosperity and equity, see Amar V. Bhidé, Non-destructive creation: How entrepreneurship sustains development, in THE EMERGENCE OF ENTREPRENEURIAL ECONOMICS 55 (Tsvi Vinig \& Roel van der Voort eds., 2005).

2 See Scott London, How Do You Change the World? Become a Social Entrepreneur, ScotT LONDON, http://www.scottlondon.com/interviews/drayton.html (last visited Mar.18, 2015).
} 
("entrepreneurial lawyers"). We then address the potential difficulties posed by law school programs that focus exclusively on training law students to be entrepreneurs in the business sector ("lawyer entrepreneurs"). Drawing on our own experiences and the writings of Bill Drayton, the lawyer who pioneered the field of social entrepreneurship, we discuss how some lawyers have applied their legal education to be successful social entrepreneurs ("lawyer social entrepreneurs"). Finally, we outline a three-year law school program explicitly designed to train law students to be lawyer social entrepreneurs, a program that we are building at the IPI.

\section{TRAINING LAW STUDENTS TO REPRESENT ENTREPRENEURS}

Lawyers and entrepreneurs make strange bed fellows. Lawyers look "backwards" at precedents while entrepreneurs look "forward" to the launch of a new business or new product. Lawyers are generally conservative and risk-adverse while their clients are almost always optimistic and willing to take chances to achieve their goals. ${ }^{3}$

This description accurately and unfortunately reflects the limits of traditional legal education and the stereotypical lawyers it trains. Traditional legal education tends to train lawyers who are left-brained: logical, analytical, and objective. That bias seems to render them poorly suited to represent entrepreneurs who are right-brained: intuitive, thoughtful, and subjective.

These simple stereotypes are obvious exaggerations, ${ }^{4}$ although the conflicting cognitive styles of entrepreneurs and lawyers do raise a "vexing question of why apparently rational executives would be willing to pay such large sums of money for the services of an unproductive troublemaker." 5 In fact, "accomplished entrepreneurs will occasionally confess, sometimes grudgingly,

${ }^{3}$ Arizona State University, National Transactional clinic conference hosted by College of Law, ASU News (June 8, 2010) (quoting Professor Thomas H, Morsch, who spoke at a Nat'l TransactionalClinicConference), https://asunews.asu.edu/20100608_TransactionalClinic Conference.

${ }^{4}$ It is, of course, a myth that people are either right-brained or left-brained. See Kendra Cherry, Left Brain $v$ Right Brain, ABOut EducATION, http://psychology.about.com/od/cognitivepsychology/a/

left-brain-right-brain.htm (last visited Apr. 15, 2015). To be successful, entrepreneurs must be analytical, just as successful lawyers must be creative. See Marty Zwilling, Is an Ideal Entrepreneur Right Brain or Left Brain?, HufF. Post (Apr. 15, 2014 5:58 PM), http://www.huffingtonpost.com/marty-zwilling/is-an-ideal-entrepreneur_b_5155730.htm; Michael Melcher, Create a Right-Brain File, CREATIVE LAWYER (Oct. 2, 2007) http://thecreativelawyer. typepad.com/the creative lawyer/2007/10/create-a-right-.html.

${ }^{5}$ Mark C. Suchman \& Mia L. Cahill, The Hired Gun as Facilitator: Lawyers and the Suppression of Business Disputes in Silicon Valley, 21 LAW \& Soc. InQuiRY 679, 680 (1996). 
but with sincere gratitude and even respect, that their lawyers were key players in their success." 6

Characterizations of these lawyers vary. Professor Ronald Gilson has compared lawyers to transaction cost engineers and reputational brokers; ${ }^{7}$ Professor George Dent sees them as "enterprise architects." Suchman's research on lawyers in Silicon Valley suggests that lawyers in that entrepreneurial economy do more than design solutions to legal and organizational problems; they also play crucial roles as moderators of the hazards of new-company formation" and act as "organizational pollinators" in the startup process. ${ }^{10}$

Thankfully, "the Silicon Valley venture capital bar has not cornered the facilitative lawyering market," 11 nor is the need for such lawyering limited to high technology economies. Professor Michael Risch's study of the evolving economy of West Virginia demonstrates that lawyers can play crucial roles everywhere in the development of founders, business plans and intellectual property. ${ }^{12}$

Preparing law students and new graduates for these roles can take many forms. Although traditional legal education may fail to produce lawyers who are trained to innovate, the Ewing Marion Kauffman Foundation's Entrepreneurship Law website currently lists more than 100 law schools that train law students to represent innovators and entrepreneurs. ${ }^{13}$

\section{A. Law Clinics}

Many of these programs are law school clinics offering legal services to innovators and entrepreneurs. Northwestern University School of Law's

\footnotetext{
${ }^{6}$ Anthony J. Luppino, The Value of Lawyers as Members of Entrepreneurial Teams, in HaNDBOOK ON LAW, INNOVATION AND GROWTH 300 (Robert E. Litan ed., 2011).

${ }^{7}$ Ronald J. Gilson, Value Creation by Business Lawyers: Legal Skills and Asset Pricing, 94 YALE L.J. 239, 255 (1984).

${ }^{8}$ George W. Dent, Jr., Business Lawyers as Enterprise Architects, 64 Bus. LAW. 279, 281 (2009).

${ }^{9}$ Suchman \& Cahill, supra note 5, at 680.

${ }^{10}$ Mark C. Suchman, The Contracting Universe: Law Firms and the Evolution of Venture Capital Financing in Silicon Valley 2 (2006); see also Mark C. Suchman, Dealmakers and Counselors: Law Firms as Intermediaries in the Development of Silicon Valley, in Understanding Silicon Valley: The Anatomy of an Entrepreneurial Region 71 (M. Kenney ed., 2000).

${ }^{11}$ Luppino, supra note 6, at 311.

12 Michael Risch, IP and Entrepreneurship in an Evolving Economy: A Case Study, in Entrepreneurship and InNOVATION In Evolving Economies: The Role of LAW 156 (Megan Carpenter ed., 2011).

13 See Entreprenueurship.org: For people growing great ideas, Law School Entrepreneurship Clinics, $\quad$ http://www.entrepreneurship.org/entrepreneurship-law/law-school-entrepreneurshipclinics.aspx (last visited Apr. 10, 2015). For an overview of these programs, see ANTHONY J. Luppino, Can Do: Training Lawyers to be EfFective Counselors to EntrepreneursREPORT TO EwING MARION KAUfFMAN FoundATION (Jan. 30, 2008), available at http://ssrn.com/abstract=1157065.
} 
Entrepreneurship Law Center teaches law students to be problem solvers, ${ }^{14}$ and the University of Missouri-Kansas City School of Law's Entrepreneurial Legal Services Clinic trains "can do" lawyers who are indispensible members of entrepreneurial teams. ${ }^{15}$ Brooklyn Law School's Brooklyn Law Incubator and Policy Clinic teaches new lawyers "who are well-versed across the spectrum of skills needed to represent emerging tech, Internet, communications, and new media companies."16 And at the University of California Hastings School of Law, the Startup Legal Garage trains law students to become "partners in enterprise and more than just "the lawyer in the room." 17

\section{B. Beyond Clinics: Classroom and Community}

A handful of law schools direct their efforts to training innovative law students via combinations of classroom and community experiences. At the University of Colorado Law School, the Tech Law Accelerator (TLA) provides a four-week summer boot camp to train future lawyers on their clients' businesses. The TLA also partners with technology companies to place its boot camp graduates in internships with in-house law departments. ${ }^{18}$

At the Innovation Practice Institute at Pitt Law, we take a three-pronged approach to preparing law students to represent entrepreneurs. First, the IPI integrates the teaching of entrepreneurship into the curriculum with courses such as "Law and Entrepreneurship," which takes law students "through the life cycle of a technology start-up company, from concept and formation to exit."19 Second, the IPI works to ensure that its law students are integrally involved in the campus-wide entrepreneurship education program at the University of Pittsburgh,

14 Bluhm Legal Clinic, Entrepreneurship Law Center, NORTHWESTERN LAw, http://www.law.northwestern.edu/legalclinic/elc/ (last visited Apr. 10, 2015).

15 UMKC School of Law Elective Course Information, Entrepreneurial Law and Practice Clinic (Fall 2013), http://law.umkc.edu/pdfs/electives/entrepreneurial-law-clinic-8757r.pdf. The "Can Do" tagline permeates many UMKC Law entrepreneurship programs, in addition to this clinic.

${ }^{16}$ BroOKLyn LAw InCUBATOR \& Policy (BLIP), http://www.blipclinic.org/ (last visited Apr. 15, 2015).

${ }^{17}$ University of California-Hastings College of Law, Institution for Innovation: Implementable Solutions, http://innovation.uchastings.edu/focus-areas/startup-legal-garage/ (last visited Apr. 10, 2015).

${ }^{18}$ See University of Colorado Boulder-Colorado Law, New Tech Accelerator Program Garners Inaugural Access Group Grant (July 17, 2014), http://www.colorado.edu/law/2014/07/17/newtech-lawyer-accelerator-program-garners-inaugural-access-group-grant.

19 See University of Pittsburgh-Pitt Law, Law and Entrepreneurship, http://www.law.pitt.edu/academics/courses/catalog/5631 (last visited Apr. 15, 2015) (this course involves careful analysis of relevant legal documents and case studies, as well as participation in lectures, workshops and simulations). 
which provides opportunities for law students to work with Pitt researchers and entrepreneurs as part of the technology commercialization process. ${ }^{20}$

Third, the IPI offers an extracurricular, community-based program entitled "Start Smart Law," a unique cross-university collaboration with Project Olympus, a Carnegie Mellon University (CMU) innovation center. ${ }^{21}$ During Start Smart Law seminars, experienced startup lawyers teach basic startup law and practice to IPI law students and CMU computer science and engineering graduate students. These seminars are open to the public as well, and attendees may include other researchers, inventors, investors, and practicing lawyers. These startup legal issues include seminars on entity formation, raising capital, intellectual property, employee relationships, and immigration law. Start Smart Law workshops follow the seminars, during which, startup lawyers and IPI staff oversee the law students as they work with their graduate student peers and other local entrepreneurs to produce "roadmaps" of legal information that will guide the entrepreneurs in their planning and decision-making process. These roadmaps are not confidential and do not constitute legal advice; however, they do educate the entrepreneurial consumer so that he or she knows the questions to ask when engaging a startup lawyer, saving the entrepreneur time and legal fees. And preparing these legal roadmaps provides IPI law students with a real-world simulation of how startup lawyers partner with entrepreneurs to advance new ventures.

\section{TRAINING LAW STUDENTS TO BE ENTREPRENEURIAL IN LAW-RELATED CAREERS}

Lawyers must think more like entrepreneurs. Clients' changing needs will demand it. The economy demands it. ${ }^{22}$

Today's law students do not just want to represent entrepreneurs. They need to be entrepreneurs, regardless of whether they pursue solo, small firm, Big Law, or other legal services careers. The ABA Journal's "Legal Rebels" series

\footnotetext{
20 The Innovation Institute at the University of Pittsburgh oversees the university's entrepreneurship program. For more information, see Innovation Institute, U. PITT., http://www.innovation.pitt.edu/ (last visited Apr. 15, 2015).

${ }^{21}$ Carnegie Mellon University and the University of Pittsburgh are located next to each other in the Oakland neighborhood of Pittsburgh. Carnegie Mellon University does not have a law school. For more information on Start Smart Law, see IPI Programs: Start Smart, InNOVATION PRACTICE InST., http://innovation-practice.net/what-we-do/ipi-programs-start-smart/ (last visited Apr. 10, 2015). For more information about Project Olympus, see Project Olympus, CARNEGIE Mellon UnIV., http://www.cmu.edu/olympus/about/index.html (last visited Apr. 10, 2015). In addition to the IPI and Project Olympus, lawyers from K\&L Gates play a leading role in presenting Start Smart Law.

${ }^{22}$ Sam Glover, Lawyers Must Evolve or Face Extinction, LeGAL ReBELS (Oct. 15, 2009, 9:00 PM), http://www.abajournal.com/legalrebels/article/sam_glover_lawyers_must_evolve_or_face_extincti on/. Sam Glover is a Minnesota-based legal entrepreneur and manages a full-time consumer rights practice.
} 
features some of these entrepreneurial lawyers. Sam Glover, founder of Lawyerist, an online lawyer's survival guide, warns that lawyers must evolve and "think more like an entrepreneur" or "risk extinction." ${ }^{23}$ Susan Cartier Liebel, founder of Solo Practice University, views solo law firm practice as "the ultimate expression of entrepreneurship." 24 And in the legal services industry, the influx of technology and venture capital financing are pressuring lawyers and law firms to be more entrepreneurial. ${ }^{25}$

In a variety of ways, law schools are connecting their students to entrepreneurial thinking and practice as lawyers. The Kauffman Foundation's Entrepreneurship Law website currently lists more than eighty law schools that offer courses or related programs that train law students to be entrepreneurs in providing legal services. ${ }^{26}$

\section{A. Incubators and Laboratories}

A growing number of law schools have created "incubators" or partnered with law practices employing their own recent graduates, which helps to develop those lawyers' skills as new solo or small office practitioners. Leading examples include the International Justice Center for Postgraduate Development at the Touro College Jacob D. Fuchsberg Law Center, ${ }^{27}$ the Solo and Small Firm Institute and Incubator at the University of Missouri-Kansas City; ${ }^{28}$ and the Alumni Law Group at Arizona State University Sandra Day O'Connor College of Law. ${ }^{29}$ A related but distinct development is a legal "residency" program operating independently of a law school but designed to hire new graduates, train them for a period of years as future solo or small firm practitioners, then transition them into their own practices. ${ }^{30}$ And the ReInvent Law Laboratory, created at the Michigan State University College of Law, teaches students to

\footnotetext{
${ }^{23} I d$.

${ }^{24}$ Jenny B. Davis, Susan Cartier Liebel: Solos' Champion, Legal Rebels (Sept. 16, 2009, 1:28 AM), http://www.abajournal.com/legalrebels/article/susan_cartier_liebel_solos_champion/.

${ }_{25}$ See Cari Sommer, How Entrepreneurship is Reshaping the Legal Industry, ForBES (July 24, 2013, 11:46 AM), http://www.forbes.com/sites/carisommer/2013/07/24/how-entrepreneurship-isreshaping-the-legal-industry/.

26 See Entreprenueurship.org: For people growing great ideas, Law School Courses, http://www.entrepreneurship.org/entrepreneurship-law/law-school-courses.aspx (last visited Apr. 10, 2015). For a list of incubator programs, see Incubator/Residency Programs, AM. BAR Ass'N, http://www.americanbar.org/groups/delivery_legal_services/initiatives_awards/program_main.html (last visited Apr. 21, 2015).

${ }^{27}$ See International Justice Center for Postgraduate Development, Touro L., http://www.tourolaw .edu/justiceCenter/?pageid=857 (last visited Apr. 15, 2015).

${ }_{28}$ See UMKC School of Law, Solo and Small Firm Practice, https://law.umkc.edu/prospectivestudents/life-after-umkc/solo-small-firm-incubator/ (last visited Apr. 10, 2015).

${ }^{29}$ See ASU Alumni Law GROUP, http://asualumnilawgroup.org/ (last visited Apr. 15, 2015).

${ }^{30}$ The model here is Fair Shake, a Pittsburgh-based not-for-profit that focuses its practice and its advocacy on representing modest means clients in environmental justice issues. See FAIR SHAKE: ENVIRONMENTAL LEGAL SERVICES, http://www.fairshake-els.org/ (last visited Apr. 15, 2015).
} 
"think of themselves as potential founders of start-ups . . . and to operate fluidly in a legal environment that is being transformed by technology." 31

\section{B. Curricular and Extracurricular Combinations}

At Pitt Law, the Innovation Practice Institute offers a framework that provides opportunities for law students to learn from and about entrepreneurial lawyers through both curricular and extracurricular programs. A classroom course entitled "Understanding the Legal Services Marketplace" teaches IPI law students about "the commercial landscape of the legal services industry" by interacting with both practicing attorneys and consumers of legal services. ${ }^{32}$ A course entitled "In-House Counsel in Modern Corporations" explores the unique legal and practical challenges that counsel face when working in corporate law departments of various sizes, including entrepreneurial contexts. ${ }^{33}$ The IPI extracurricular weekly "Innovators, Esq." lunchtime speakers' series gives law students the chance to interact with entrepreneurial lawyers who have been innovative in law-related careers, including lawyers who have: moved from solo practices to law firms and vice versa; moved back and forth between private law practice and in-house positions; developed innovative business and organizational practices inside law firms; and built law-related technologies and startups.

\section{TRAINING LAW STUDENTS TO BE LAWYER ENTREPRENEURS IN NON-LEGAL CAREERS}

Anyone who is intelligent enough and has worked hard enough to become a lawyer can become a success in a myriad of fields. ${ }^{34}$

Tim and Nina Zagat were working as successful corporate lawyers when a dinner party conversation about lousy restaurant reviews changed their lives. What started as an informal survey printed on legal size paper grew into the

\footnotetext{
${ }^{31}$ John Schwartz, This is Law School?, N.Y. Times (Aug. 1, 2014), http://www.nytimes.com/2014 /08/03/education/edlife/socrates-takes-a-back-seat-to-business-and-tech.html; see also ReInvent Law Laboratory, Мich. ST. UNIV. L. http://www.reinventlaw.com/main.html (last visited Apr. 10, 2015).

32 See University of Pittsburgh-Pitt Law, Understanding the Legal Services Marketplace, available at http://www.law.pitt.edu/academics/courses/catalog/5133 (last visited Apr. 10, 2015).

${ }_{33}$ See University of Pittsburgh-Pitt Law, In-house Counsel in Modern Corporations, available at http://law.pitt.edu/node/20745 (last visited Apr. 15, 2015).

34 JD Bliss, Interview: Tim Zagat: From Law to Leisure Guide Empire (Mar. 13, 2007), http://www.jdblissblog.com/2007/06/interview-tim-z.html. Tim Zagat co-founded his company with his wife, Nina Zagat, who is also a graduate of Yale Law School. Zagat, About Us: Tim \& Nina Zagat, https://www.zagat.com/about-us/tim-and-nina-zagat (last visited Apr. 10, 2015).
} 
"world's original provider of user-generated content." 35 By 2005, the Zagat Survey covered seventy cities. In 2011, Google acquired the company for a reported $\$ 151$ million. ${ }^{36}$

The Zagats are neither the first nor the only lawyers to leave the practice of law to become entrepreneurs in non-legal fields ("lawyer entrepreneurs"). Forbes Magazine recently profiled four women who "changed hats" by leaving the practice of law to become entrepreneurs in retail, construction, food service, and real estate. ${ }^{37}$ U.S. News \& World Report featured several lawyer entrepreneurs and even proposed entrepreneurship as one of three common career options pursued by law graduates who choose not to practice law. ${ }^{38}$ The Harvard Law Entrepreneurs Network boasts that their alumni have been "very successful across a variety of industries." ${ }^{39}$

Despite these positive portrayals of lawyer entrepreneurs, a number of lawyer entrepreneurs have reported that their legal education was an impediment to becoming a successful lawyer entrepreneur. The American Bar Association Journal featured a troubling article entitled "Lawyer-Turned-Entrepreneur Says He Had to Overcome His Legal Training to Succeed."40 In an article entitled "Why Most Lawyers Make Terrible Entrepreneurs," a lawyer entrepreneur writes that "thousands of lawyers make the leap every year, [but] it's been my observation that very few succeed." 41

Training law students to be lawyer entrepreneurs in non-legal fields raises a number of practical questions, including whether there are a sufficient number of students interested in becoming lawyer entrepreneurs to warrant the development of a program to support that ambition, and, of course, the staffing and content of the program itself. It has long been true that many individuals with law degrees do not work as lawyers, but it is difficult to determine the number or proportion of those who focus on lawyer entrepreneurship of one sort or another.

${ }^{35}$ Zagat, About Us: Our History, https://www.zagat.com/about-us/our-history (last visited Apr. 10, 2015).

${ }^{36}$ Zagat, WiKIPEDIA http://en.wikipedia.org/wiki/Zagat (last visited Apr. 10, 2015).

${ }^{37}$ See Sommer, supra note 25; see Angela Haines, Changing Hats: Lawyers Turn Entrepreneurs, ForBes (Sept. 19, 2011, 4:00 PM), http://www.forbes.com/sites/85broads/2011/09/19/changinghats-lawyers-turn-entrepreneurs/\#comment_reply.

${ }^{38}$ See Shawn P. O'Connor, Three Careers Law School Graduates Should Consider Outside the Legal Field (May 19, 2014), http://www.usnews.com/education/blogs/law-admissionslowdown/2014/05/19/3-careers-for-law-school-graduates-outside-the-legal-field.

${ }^{39}$ Antonia Floyd, The Harvard Law Entrepreneur Network: About, http://hlawtrepreneurs.com/ about/ (last visited Apr. 10, 2015).

40 Debra Cassens Weiss, Lawyer-Turned-Entrepreneur Says He Had to Overcome His Legal Training to Succeed, ABA JouRnAL (Nov. 10, 2011, 11:29 AM), http://www.abajournal.com/ news/article/lawyer-turned-entrepreneur_says_he_had_to_overcome_his_legal_training/.

41 Jonathan Fields, Why Most Lawyers Make Terrible Entrepreneurs, PsYCH. ToDAY (Aug. 1, 2013), https:/www.psychologytoday.com/blog/awake-the-wheel/201308/why-most-lawyers-maketerrible-entrepreneurs. 
Assuming that a sufficient cohort of students exists to justify developing a program that focuses on entrepreneurship in both law-related and non-legal fields, a number of different program approaches can be used. For instance, programs that train their students to represent entrepreneurs and to be entrepreneurs in law-related fields do teach at least some of the skills needed to be entrepreneurs in non-legal fields. Producing extracurricular programming that introduces students to lawyer entrepreneurs provides another relatively easy and important opportunity to explore entrepreneurship in non-legal fields. At Pitt Law, for example, the Innovation Practice Institute uses this strategy as part of our Innovators, Esq. lunchtime speakers' series to engage students with numerous lawyer entrepreneurs, including:

- A lawyer turned sports marketing executive;

- A real estate lawyer turned real estate developer;

- An in-house intellectual property lawyer who is also a successful inventor and author;

- A corporate lawyer turned chief financial officer and angel investor;

- A labor litigator who launched a startup to teach organizations how to create a civil workplace, and

- A city government lawyer turned country musician.

Introducing students to these lawyer entrepreneurs typically provides a useful insight or spark for students seeking to learn about non-traditional careers. Equally important, in many cases introductions over lunch blossom into longer lasting acquaintances and even jobs. ${ }^{42}$

Like programs at some other law schools, the IPI has also developed a curriculum that exposes students to entrepreneurship in non-legal fields through courses co-taught by law and professors in other schools and departments. ${ }^{43}$ For

42 The University of Colorado recently announced the launch of the thematically similar "Entrepreneurs in Residence" program. Instead of bringing law students into frequent but brief contact with a range of lawyer entrepreneurs, Colorado Law is bringing a small number of entrepreneurs to the law school to engage deeply with students. See Karen Sloan, Colorado Law Launches First Campus Entrepreneur Program, NAT'L L.J. (Apr. 1, 2015) available at $\mathrm{http}: / /$ www.nationallawjournal.com/id=1202722325554/Colorado-Law-Launches-First-CampusEntrepreneur-Program?slreturn=20150315131239.

43 University of Pittsburgh-Pitt Law, Commercializing New Technologies, http://www.law.pitt.edu/academics/courses/catalog/5135 (last visited Apr. 10, 2015); University of Pittsburgh-Pitt Law, Law, Entertainment and Social Enterprise, http://www.law.pitt.edu/ academics/courses/27211-0 (last visited Apr. 10, 2015). Emory University law students and business, science, and engineering students at the Georgia Institute of Technology (Georgia Tech) collaborate start-up projects through the TI:GER program. See TI:GER ${ }^{\circledR}$ Program, EMORY LAW, http://law.emory.edu/academics/academic-programs/ti-ger.html (last visited Apr. 21, 2015). On the development of a similar partnership at UMKC see Anthony J. Luppino, Minding More Than Our Own Business: Educating Entrepreneurial Lawyers Through Law School-Business School Collaborations, 30 W. New ENG. L. REv. 151 (2007). 
instance, the IPI's "Commercializing New Technologies" course is taught by a member of Pitt's business school faculty and an adjunct professor at Pitt Law, a lawyer entrepreneur who also worked for a local startup incubator.

Where local conditions make it feasible, these courses can be supplemented by placing law students in the middle of entrepreneurial activities beyond the law school, particularly elsewhere at the university. ${ }^{44}$ At Pitt Law, the IPI has connected its students to team-based research commercialization activities at the Swanson School of Engineering, through the Coulter Translational Research Partners II Program. Law students collaborate with business students and engineering students on teams that support full-time faculty researchers in developing proposals to commercialize bioengineering research. ${ }^{45}$ The IPI also connects interested students with summer internships that "embed" its students in a local startup incubator, which allows them to experience the business side entrepreneurship in a variety of non-legal fields.

The IPI also mentors law student teams that enter business plan competitions both at the University of Pittsburgh and at local and regional business incubators. And like many law schools, the IPI also connects their prospective lawyer entrepreneurs with entrepreneurship programming through joint degree programs, particularly JD/MBA programs, and through internships in university technology transfer offices. ${ }^{46}$

Despite the success of these programs, one frequent concern raised in discussions of lawyer entrepreneurs working in business fields is ethics. To what extent are ethical frameworks that inform and guide lawyers and the legal profession compromised when legal training is so explicitly blended with the rhetoric and practice of for-profit entrepreneurship? We do not suggest that lawyers are necessarily ethical, nor that business entrepreneurs necessarily are not. Still, it is not hard to imagine situations where a lawyer's professional training and ethical restrictions might conflict with an entrepreneur's financial bottom line. In the next Part, we suggest one field of entrepreneurship where lawyers' professional and ethical obligations may give them a competitive advantage: the growing field of social entrepreneurship.

\footnotetext{
${ }^{44}$ Laura L. Hollis, Why - and how - law schools need to teach entrepreneurship, UNIV. OF NOTRE DAME, MENDOZA COLL. OF BuS., http://www.entrepreneurship.org/ /media/Entrepreneurship/Files /eLaw/Why\%20law\%20schools\%20need\%20to\%20teach\%20entrepreneurship.pdf (last visited Apr. 10, 2015) (recommending that law schools should be integrated in campus-wide entrepreneurship education programs).

${ }^{45}$ Coulter Translational Research Partners II Program, COUlteR PITT, http://www.engineeringx. pitt.edu/coulter/ (last visited Apr. 15, 2015) (describing the full program).

${ }^{46}$ Pitt Law students work in technology transfer offices both at the University of Pittsburgh and at Carnegie Mellon University.
} 


\section{TRAINING LAW STUDENTS TO BE LAWYER SOCIAL ENTREPRENEURS}

\section{A. The Synergy Between Lawyers and Social Entrepreneurs}

What defines a social entrepreneur is the motivation from deep within to serve the whole and to make sure that solutions are sustainable, fair, and efficient. ${ }^{47}$

In the view of many admirers, "no one has done more to put social entrepreneurship on the map than Bill Drayton." 48 While still a law student at Yale, Drayton launched a social enterprise that engaged one-third of his classmates in drafting legislation. ${ }^{49}$ During the 1980s, Drayton "coined" the term "social entrepreneur" and founded Ashoka, the world's largest network of social entrepreneurs. ${ }^{50}$ Over the last twenty-five years, Ashoka has funded and connected over 3,000 social entrepreneurs in seventy countries. ${ }^{51}$

Although Bill Drayton may be the most famous lawyer social entrepreneur, we know that he is far from the only lawyer participating in this movement. After leaving the practice of law in the late 1990s, one of the authors - Stephanie Dangel - spent a decade promoting and producing social enterprise entertainment, i.e., entertainment that is both socially meaningful and commercially viable. ${ }^{52}$

Since 2013, we have worked to recruit a wide range of lawyer social entrepreneurs to speak at and engage students, faculty, staff, and graduates through the IPI's Innovators, Esq. speaker series. The following are a few of the lawyer social entrepreneurs who have spoken over the last two years:

\footnotetext{
${ }^{47}$ Scott London, How Do You Change the World? Become a Social Entrepreneur, SCOTt London, http://www.scottlondon.com/interviews/drayton.html (last visited Mar. 18, 2015) (quoting Bill Drayton).

${ }^{48} I d$.

49 Stanford Technology Ventures Program, Bill Drayton, ECORNER: STAN. U. EnTREPRENEurshiP CORNER, http://ecorner.stanford.edu/author/bill_drayton (last visited Mar. 18, 2015).

${ }^{50}$ See, e.g., Ashoka, Celebrate Global Entrepreneurship Week with Quotes from The Man Who Coined The Term Social Entrepreneur, ForBes (Nov. 15, 2001, 11:18 AM), http://www.forbes. $\mathrm{com} /$ sites/ashoka/2012/11/15/celebrate-global-entrepreneurship-week-with-quotes-from-the-manwho-coined-the-term-social-entrepreneur/.

${ }^{51}$ For more information about Ashoka, see AsHOKA, https://www.ashoka.org/ (last visited Apr. 10, 2015).

52 After clerking for Judge Pierre Leval and Justice Harry Blackmun, Stephanie practiced law at K\&L Gates where she worked with both for-profit and non-profit clients. She subsequently worked for the Pittsburgh-based non-profit Steeltown Entertainment Project where she produced two documentaries, "My Tale of Two Cities," a documentary about Pittsburgh's post-steel renewal, and "A Shot to Save the World," a Smithsonian Channel and BBC documentary about Jonas Salk's and Bill Gates' battle to eradicate polio. Working with former Wall Street lawyers, Susan Schwartz of K\&L Gates and the late Ellen Weiss Kander, Stephanie also launched a for-profit subsidiary of the non-profit Steeltown, which has helped to fund numerous social enterprise entertainment projects.
} 
- A litigator who left his law firm to start a social enterprise incubator;

- A former United States Attorney who now heads a foundation that encourages innovation to address social issues;

- A former Fortune 500 lawyer who now incubates clean energy, advanced manufacturing, and materials startups;

- A corporate attorney who directs a foundation that is advancing learning innovation;

- An in-house energy lawyer who formed his own company to develop and supply energy to developing countries; and

- A lawyer turned entrepreneur who launched a publicprivate partnership to support underserved entrepreneurs.

Given Pittsburgh's strong history of philanthropy, ${ }^{53}$ we initially thought these lawyer social entrepreneurs might be part of a regional phenomenon. Yet, when we looked for national examples, we found more lawyer social entrepreneurs, including:

- Lawyers who are organizing funding for environmental and social justice litigation; ${ }^{54}$

- Lawyers who are crowd-funding to raise legal fees for indigent clients; $; 5$

- Transactional lawyers who are crowd-sourcing solutions for fellow social entrepreneurs; ${ }^{56}$

- Government lawyers who are launching national offices to empower social entrepreneurs; ${ }^{57}$ and

- Clinical law professors who are teaching their students to represent social entrepreneurs. ${ }^{58}$

53 See Emily Yarrison, A legacy of philanthropy: How foundation support benefits Pittsburgh, today and tomorrow, POP CITY, (Mar. 25, 2015) http://www.popcitymedia.com/features/ philanthropy_032515.aspx.

${ }^{54}$ See JustiCE InVESTOR, www.justiceinvestor.com (last visited Apr. 9, 2015).

55 See Martha Neil, New crowdfunding site helps individuals raise money for legal fees, ABA J. (Dec. 15, 2014, 11:10 AM), http://www.abajournal.com/news/article/new_litigation_crowdfunding site_seeks_to.

$\overline{56}$ See David Roll, Legal Issues for Social Entrepreneurs, LAwFORCHANGE, http://www.lawfor change.org/NewsBot.asp?MODE=VIEW\&ID=3592 (last visited Apr. 15, 2015).

57 In 2009, President Obama launched the White House's first Office of Social Innovation and Civic Participation. See Office of Social Innovation and Civic Participation, THE White House, http://www.whitehouse.gov/administration/eop/sicp (last visited Mar. 18, 2015).

58 See Ashoka, How Law Schools and Entrepreneurs Collaborate to Serve Both Students and Innovators, FoRBES (Dec. 7, 2012, 12:06 PM), http://www.forbes.com/sites/ashoka/2012/12/07/ how-law-schools-and-entrepreneurs-collaborate-to-serve-both-students-and-innovators/. 
Anecdotes do not make a movement, but we believe that the salience of lawyers in the ranks of social entrepreneurs is neither a coincidence nor an educational opportunity to be overlooked. Is there some synergy between the roles of lawyers and social entrepreneurs? Based on our experience and those of other lawyer social entrepreneurs, as well as literature on social entrepreneurship, we believe that lawyers and social entrepreneurs do share many important qualities and that those affinities offer us an important opportunities as educators.

The first similarity is the easiest to understand: Social entrepreneurs frequently confront legal obstacles. In a recent poll conducted by the Social Enterprise Alliance, $71 \%$ of social entrepreneurs reported that finding "the best legal structure for their ventures was the single greatest challenge they faced." 59 And of the 3,000 Ashoka social entrepreneurs, approximately 800 of them are pursuing missions involving law to varying degrees. ${ }^{60}$

Lawyers and social entrepreneurs also share a similar mindset or approach to the problems they confront. For example,

- Like lawyers who are taught to serve the interests of their clients and the interests of justice, social entrepreneurs also serve (at least) two masters - their social mission and their need for economically (and in some cases environmentally) sustainable solutions.

- Like lawyers who are trained to see issues from multiple perspectives, social entrepreneurs must see issues from both social and economic perspectives, as well as from the varying perspectives of the constituencies they need to unite to accomplish their missions. ${ }^{61}$

- Like lawyers, social entrepreneurs must be both visionary and practical. While a lawyer must understand

59 See B. Ray Dining, Structuring Social Ventures: Choice of Legal Structure, VERITAS VentURE CAPITAL FOR Micro FINANCE IN AFRICA (Nov. 29, 2009), https://veritasvc.wordpress.com/2009/

$11 / 29$ /structuring-social-ventures-by-b-ray-dinning-jd-1lm/. It is admittedly ironic to think that social entrepreneurs find the choice of legal structure to be a greater challenge than their "life purpose," which is "to change the world." Not surprisingly, lawyer social entrepreneur Bill Drayton does not find the choice of a for-profit legal structure to be a challenge: "Everyone says, you've got to do a foundation and legal structure to finance social change. What nonsense!" Fast Company Staff, $Q \& A$ : Bill Drayton, FAST COMPANY (Dec. 1, 2007), http://www.fastcompany.com/ 693594/qa-bill-drayton.

60 This rough approximation is based on a keyword search for "law" in the Ashoka Fellow descriptions found at https://www.ashoka.org/fellows?country=All\&keys=law\&tid=All\&tid 1=All\&tid_2=All\&term_node_tid_depth=All. See, e.g., Asoka Innovators For The Public, Fellow Samisdar, $\bar{h}$ ttps://www.ashoka.org/fellow/samsidar (last visited Apr. 9, 2015) (describing an Ashoka Fellow in Indonesia who is assisting women victims seeking legal redress).

${ }^{61}$ Although the details of the definition of social entrepreneurship vary, the balancing of social mission and financial sustainability is central to the field. See, e.g., Samer Abu-Saifan, Social Entrepreneurship: Definition and Boundaries, TIM REVIEW (2012), available at http://timreview .ca/article/523. 
the client's ultimate objective, the lawyer must also be able to apply broader legal principles to a specific set of facts.

- A successful lawyer, like an accomplished social entrepreneur, must be "double dominant," meaning must possess the ability to use both her left and right brain. A lawyer and a social entrepreneur both need "a poem and an engineering drawing" 62 to solve the challenges before them.

- Like lawyers, social entrepreneurs must be "social," which requires them to be good communicators and to possess strong emotional intelligence capabilities. Persuasion is key. Making a pitch to a funder, be it forprofit, non-profit, or governmental, is like arguing a case before a judge or mediator. Writing a grant proposal is like drafting a brief, with previously awarded grants serving as "precedents."

- Lawyers have played an important role in advancing other forms of "new" entrepreneurship akin to social entrepreneurship, including norm entrepreneurship, policy entrepreneurship, moral and civic entrepreneurship. ${ }^{63}$

- Lawyers, like social entrepreneurs, must be comfortable with both complexity and ambiguity. Humorously, Tony Sheldon of the Yale Social Enterprise program has invoked United States Supreme Court Justice Potter Stewart in trying to define social entrepreneurship: "Social entrepreneurship is a little like pornography. It's hard to define, but you know it when you see it." 64

Finally, and most importantly, social entrepreneurs are leaders, which is a role long played by lawyers. In the twentieth century, law schools trained lawyers who went on to become leaders in law firms, for-profit businesses, nonprofit organizations, and in government offices. In the twenty-first century, social entrepreneurs will be the leaders who "recognize when a part of society is

\footnotetext{
${ }^{62}$ See Caroline Hartnell, Interview - Bill Drayton, Alliance (Mar. 1, 2000), http://www.alliance magazine.org/interview/interview-bill-drayton/.

63 See David A. Pozen, We Are All Entrepreneurs Now, 43 Wake Forest L. Rev. 283 (2008) (describing legal origins of social, norm, policy and moral entrepreneurs); see also Harold Hongju Koh, The 1998 Frankel Lecture: Bringing International Law Home, 35 Hous. L. REv. 623, 646-55 (1998). UMKC Law offers a course on law and civic entrepreneurship, entitled Law, Technology and Public Policy. See http://law.umkc.edu/pdfs/electives/special-topics-law-tech-pub-policy8921.pdf

${ }^{64}$ Social Entrepreneurship in the Age of Atrocities 1 (Zachary D. Kaufman ed., 2012).
} 
not working and solve the problem by ... persuading entire societies to take new leaps." ${ }_{65}$ It is up to law schools to ensure that their graduates are well prepared for leadership as social entrepreneurs. ${ }^{66}$

\section{B. Why Law Schools Should Train Law Students to be Lawyer Social Entrepreneurs}

Social entrepreneurs can only come to rest when their vision has become the new pattern all across society. ... To succeed, many of the laws and frames of mind that today divide the world will have to change. There is tremendous work here for the law schools. ${ }^{67}$

Based on our personal experience and conversations with other lawyer social entrepreneurs, we believe that their legal education played a key role in preparing them to be social entrepreneurs. That is the good news. The bad news is that there are not nearly as many lawyer social entrepreneurs as there should be or can be. Of the 800 Ashoka fellows working on projects involving law, fewer than eighty of those fellows appear to be lawyers ${ }^{68}$ - and that includes Bill Drayton, the lawyer founder of Ashoka, who presumably understands the value of legal training for social entrepreneurs.

The lack of more lawyer social entrepreneurs is unfortunate for a number of reasons. In terms of jobs, the dearth of lawyer social entrepreneurs is a missed opportunity for underemployed law school graduates. According to Drayton, what he refers to as "the citizen sector," which includes both non-profit and nongovernmental sectors, ${ }^{69}$ is the fastest growing economic sector, generating jobs

65 See Bill Drayton, Everyone a Changemaker, 7 PEER REV. 3 (2005), http://www.aacu.org/publications-research/periodicals/everyone-changemaker.

${ }^{66}$ For descriptions of the roles that lawyers can play in emerging economic and cultural organizations, see Janelle Orsi, Practicing Law in the Sharing Economy: Helping People Build CoOperatives, Social Enterprise, and Local Sustainable Economies (2012); Jenny Kassan \& Janelle Orsi, The Legal Landscape of the Sharing Economy, 27 J. ENVTL. L. \& Litig. 1 (2012)..

67 See Bill Drayton, Everyone a Changemaker: Social Entrepreneurship's Ultimate Goal, INNOVATIONS (Feb. 22, 2007), http://www.policyinnovations.org/ideas/innovations/data/ changemakers.

68 This approximation is based on a keyword search for "lawyer" among the database of Ashoka fellows. See Ashoka Innovators For The Public, Keyword Search, https://www.ashoka.org/fellows? country $=$ All\&keys $=$ lawyer\&tid $=$ All\&tid_1=All\&tid_2 $=$ All\&term_node_tid_depth=All (last visited Apr. 10, 2015). See, e.g., Ashoka Innovators For The Public, Fellow Abbass, https://www.ashoka.org/fellow/abbass-abbass (last visited Apr. 10, 2015) (Abbass is a lawyer working to improve the lives of disabled Arabs in Israel).

${ }^{69}$ Drayton's use of the term "citizen sector," as opposed to "non-profit" and "non-governmental sector," provides an excellent example of how he brings a lawyer's precise use of language to the field of social entrepreneurship. "One cannot constructively or effectively define anything by what it is not. Moreover, by calling us 'non-government', one suggests a conflict with government that is not and certainly should not be there. Similarly 'non-profit' suggests, at best, foreignness to the business reader.” See Bill Drayton, Words Matter, 12 Alliance 2 (2007). 
two and a half to three times as fast as the business sector. ${ }^{70}$ The number of U.S. citizen groups has doubled since $1990,{ }^{71}$ and from 1990 to 2000 , the number of registered international citizen groups increased by $650 \% .{ }^{72}$ In Brazil alone, the number of such groups grew from 5,000 in 1980 to 1,000,000 in 2000. ${ }^{73}$ "There are now millions of modern, competing citizen groups, including big, sophisticated second-generation organizations," $" 74$ many of which could provide much-needed job opportunities for law school graduates.

The lack of more lawyer social entrepreneurs also suggests a failure of law schools to respond to the interests of their current and prospective students. We have met lawyers who skeptically view social entrepreneurship as a socialism best avoided or as a fad destined to disappear - but those lawyers do not belong to the current generation of students, who, given the global financial crisis, are often suspicious of strictly business or governmental solutions. ${ }^{75}$ The pervasiveness of social media and marketing has led one of us (Stephanie Dangel) to call today's students the "Toms shoes" generation, after the for-profit footwear company known primarily for donating shoes to children in need on a one-sold-to-one-donated basis. ${ }^{76}$ As trite as it may sound, today's students are potential social entrepreneurs from the soles of their feet to the souls in their hearts. ${ }^{77}$

Whether the match between legal education and social entrepreneurship is based on career opportunities or on shifting student aspirations, over the past eighteen months at the Innovation Practice Institute we have been overwhelmed by the interest of our students in innovation and entrepreneurship, particularly social entrepreneurship. More than 175 law students have participated in IPI programming that has introduced them to, or trained them to be, lawyers who

\footnotetext{
${ }^{70}$ See Drayton, supra note 67.

${ }^{71}$ Bill Drayton, Needed: A New Social Financial Services Industry, 9 Alliance 1 (2004).

${ }^{72}$ See id.

${ }^{73}$ See id.

${ }^{74}$ Drayton, supra note 67.

${ }^{75}$ See David Bornstein, The Rise of the Social Entrepreneur, N.Y. TIMES (Nov. 13, 2012), http:/opinionator.blogs.nytimes.com/2012/11/13/the-rise-of-social-entrepreneur/; Giles Hutchins, Social Entrepreneurship and Generation $Y-A$ Match Made in Heaven, THE NATURE OF Business (Dec. 21, 2012), http://thenatureofbusiness.org/2012/12/21/social-entrepreneurship-and-generationy-a-match-made-in-heaven/.

76 See Toms, http://www.toms.com (last visited Apr. 13, 2015). Some commentators, including Drayton, have understandably questioned whether Toms qualifies as true social entrepreneurship. See Neil Parmer, How to Know If You're Really a 'Social Entrepreneur', Inc. (July 8, 2014), http://www.inc.com/neil-parmar/how-to-know-if-you-re-really-a-social-entrepreneur.html.

However, it is difficult to avoid the conclusion that the marketing campaign of this company is consistent with the familiarity of today's students with companies that blend doing well and doing good.

77 For further evidence of the student interest in social entrepreneurship, see John Tyler, Evan Absher, Kathleen Garman \& Anthony Luppino, Producing Better Mileage: Advancing the Design and Usefulness of Hybrid Vehicles for Social Business Ventures, 33 QUINNIPIAC L. REV. 235 (2015) (article on hybrid entity forms for social ventures co-authored by Professor Luppino, John Tyler of the Kauffman Foundation, and two UKMC law students, who are social and civic entrepreneurs).
} 
work with and who are innovators and entrepreneurs. While not all of these programs dealt specifically with social entrepreneurship, our students have consistently raised a related and significant question: How do I balance my desire to do well financially with my desire to do good in the world?

\section{The Innovation Practice Institute's Proposal to Train the Next Generation of Lawyer Social Entrepreneurs}

The Innovation Practice Institute at Pitt Law is currently developing a pilot version of a three-year program to train law students to become social entrepreneurs via a wide variety of career options, including some more conventional routes (as legal practitioners in private law practice, government service, or as in-house counsel) and some less conventional (as social entrepreneurs in for-profit, non-profit, or hybrid entities). As the text below indicates, parts of this program are already being piloted by the IPI. Over the next year, we will continue to develop this program into a professional education framework that is experiential and forward-looking, grounded in community engagement and partnerships with legal and non-legal organizations.

Based on the experience of Stephanie Dangel in launching a social enterprise, our three-year program will follow what we see as the three stages required to launch such a venture. In brief, these three stages require social entrepreneurs to:

(1) Identify a social innovation that is commercially promising;

(2) Incubate the social innovation until is commercially viable; and

(3) Invest in the social innovation so that it can become commercially sustainable.

These three stages align with the three years of law school. In brief, to train law students to be social entrepreneurs, the IPI will:

(1) Identify law students interested in social entrepreneurship through extra-curricular events;

(2) "Incubate" these law students through team-based social enterprise courses and internships; and

(3) Invest in these law students through subsidized positions at new or currently existing social enterprises.

The first year of the program will focus in part on extracurricular events, as the courses during the first year of law school are traditionally mandatory. During the first semester, Innovator, Esq. lunchtime presentations will prominently feature lawyer social entrepreneurs from a wide-range of fields. The 
IPI's Start Smart Law seminars will enlist lawyers who represent social entrepreneurs to train Pitt Law students and local social entrepreneurs to advance social ventures. The IPI will also leverage other Pitt Law resources that focus on helping new law students develop their identities as members of the legal profession. A year-long mandatory first-year course entitled "Pitt Law Academy" brings members of the profession to the law school as guest lecturers on a wide range of subjects, from forms of practice to work-life balance issues. ${ }^{78}$

During the first year, students serious about exploring the field of social entrepreneurship will also be invited to participate in the IPI's extracurricular "Leadership Forum."79 The forum will focus on the three qualities of an effective social entrepreneur and begin to address how these qualities specifically apply to lawyer social entrepreneurs.

First, an effective social entrepreneur "must be creative in both goalsetting and problem-solving." ${ }^{\circ 0}$ By drawing on case studies of Ashoka Fellows who are lawyer social entrepreneurs working in a variety of fields, ${ }^{81}$ the law students will learn how to use their legal training to solve social problems. Drayton explains that while "the professional succeeds when she solves a client's problem . . . Social entrepreneurs can only come to rest when their vision has become the new pattern all across society." ${ }^{2}$ Law students will also begin to visualize their own paths to becoming a lawyer social entrepreneur through creative leadership development exercises. ${ }^{83}$

Second, an effective social entrepreneur must have an entrepreneurial quality. ${ }^{84}$ "What is that? It's not getting things done or leading or managing . . . [i]t's a deep drive to change society for the good of all. . ." 85 Drawing on

\footnotetext{
78 See University of Pittsburgh-Pitt Law, Pitt Law Academy Message For All $1 L$ Students, http://www.law.pitt.edu/pitt-law-academy-message-all-1l-students (last visited Apr. 15, 2015).

79 For students interested in becoming lawyer social entrepreneurs, this Leadership Forum will build on the success of the IPI Leadership Forum, a ten-hour classroom experience taught by the IPI's Faculty Director, Professor Michael Madison. See IPI Leadership Forum, InNOVATION PRACTICE INST., http://innovation-practice.net/what-we-do/ipi-leadership-forum/ (last visited Apr. 15, 2015). Although this program is voluntary, extracurricular, and not-for-credit, over the last two years Pitt Law staff, alumni, and twenty students have completed the program. See Michael J. Madison, Leading New Lawyers: Leadership and Legal Education, U. OF PitTSBURGH LegaL StUdies RESEARCH PAPER No. 2015-12 (Apr. 16, 2015), available at http://ssrn.com/abstract=2595351.

${ }^{80}$ See Drayton, supra note 65, at 8.

${ }^{81}$ See, e.g., Ashoka Innovators For The Public, Fellow Andrade, https://www.ashoka.org/fellow/ juan-andrade (last visited Apr. 10, 2015) (Andrade has formed a grass-roots social movement to rehabilitate and empower street children and eradicate the forces that compel children to the streets).

${ }^{82}$ Drayton, supra note 65 , at 8.

83 Michael F. Melcher, The Creative Lawyer: A Practical Guide to Authentic PROFESSIONAL SATISFACTION (2007).

${ }^{84}$ Drayton, supra note 65 , at 8 .

85 Bill Drayton, How to Be a Change Agent, FAITH \& LeAdershiP (Mar. 28, 2011), http://www.faithandleadership.com/qa/bill-drayton-how-be-change-agent.
} 
materials from Ashoka U, ${ }^{86}$ law students will learn that "everyone's a changemaker," or, in other words, "anyone can apply the skills of changemaking to solve complex social problems." ${ }^{87}$ However, in a world increasingly defined by change, lawyer social entrepreneurs must understand that their "[v]alue . . . comes not from providing the same thing over and over to a client, but from managing kaleidoscopic change processes that are busily bumping one another." 88

While change is crucial, change alone not sufficient for a social entrepreneur. "Changing the world's systems is what defines entrepreneurship. Doing so for the good of all is what defines social entrepreneurs." ${ }^{9}$ A legal education that trains law students to balance their duties to their clients and the interests of justice should also serve to train them to be social entrepreneurs who pursue change for the "good of all."

Third, a social entrepreneur must have ethical fiber, ${ }^{90}$ because "[p]eople will not make significant changes in their lives if they do not trust the person asking them to do so." ${ }^{1}$ With respect to lawyer social entrepreneurs, law students will learn that

[a]s change accelerates and as the world becomes more complex, the rules cover less and less. They have not been invented. They are changing. They are in conflict. Anyone living only by rules-based ethics will unavoidably hurt others and disrupt groups ... [people] need different skills. They must master empathy. . . .92

Drawing on materials from Ashoka's Start Empathy initiative, law students will learn that empathy means much more than "the ability to understand what someone is feeling."

${ }^{86}$ AshoKA U., http://ashokau.org/ (last visited Apr. 10, 2015). Another important source of materials relevant to training lawyer social entrepreneurs is the United States Association for Small Business and Entrepreneurship (USASBE) Social Entrepreneurship Certificate Program - see http://law.umkc.edu/mwse/usasbe-certificate/. USASBE collaborates with UMKC and the Kauffman Foundation to co-host an annual Midwest Symposium for Social Entrepreneurship. See the Symposium website at http://law.umkc.edu/mwse/ and http://www.usasbe.org/events/event_details.asp?id=599145, and http://law.umkc.edu/mwse/ .

87 Ashoka Innovators for the Public, Vision and Mission, https://www.ashoka.org/visionmission (last visited Apr. 10, 2015).

88 Bill Drayton, A Team of Teams World, Stan. Soc. Innovation Rev. (Spring 2013), http://www.ssireview.org/articles/entry/a_team_of_teams_world.

89 Bill Drayton, Foreword, in Beverly Schwartz, Rippling: How Social Entrepreneurs SPREAd InNOVATION THROUGHOUT THE WORLD (2012).

${ }^{90}$ Drayton, supra note 65 , at 8.

91 Paul Light, The Four Components of Social Entrepreneurship, SKOLl WORLD Forum (2008), available at http://skollworldforum.org/2008/09/30/the-four-components-of-socialentrepreneurship/.

92 Bill Drayton, Bill Drayton: Empathy-Based Ethics: A Strategic Essential, ForBes, INDIA (2012), http://forbesindia.com/article/third-anniversary-special/bill-drayton-empathybased-ethics-astrategic-essential/32952/1\#ixzz3U5j4ISKT (emphasis added). 
It means the ability to grasp the many sides of today's complex problems and the capacity to collaborate with others to solve them; it means being as good at listening to the ideas of others as articulating your own; it means being able to lead a team one day, and participate as a team member the next. ${ }^{93}$

For Drayton and other lawyer social entrepreneurs, empathy is the twenty-first century skill that is "the foundation for everything else." 94

After students complete their leadership training, during both the students' first and second years the IPI will also work with Pitt Law's Office of Career Planning and Development (OPCD) to find these students summer internships working with lawyer social entrepreneurs. Pitt Law is attuned to such opportunities as it is now has on its staff a career counselor specifically focused on matching law students and graduates with jobs and careers for which bar passage is not required. In addition, through its Innovators, Esq. and Start Smart Law events, the IPI has engaged alumni lawyer social entrepreneurs willing to mentor similarly inclined students.

For example, during the Summer of 2014 Pitt Law students interned at Thrill Mill, a Pittsburgh incubator/accelerator founded by a lawyer social entrepreneur. ${ }^{95}$ By "embedding" law students at Thrill Mill, with practicing lawyers supervising their work, the IPI and its students have begun to play an important role in Pittsburgh's social entrepreneurial ecosystem. The IPI is currently working with other incubators and accelerators in the Pittsburgh region to provide additional opportunities to similarly "embed" law students.

During their second year of the pilot, law students will participate in experiential, team-based courses that will focus on "incubating" social innovations. The ability to work in teams is an essential skill for social entrepreneurs: "Because one needs to see and seize ever-changing opportunities, the new organizational model must be a fluid, open team of teams." ${ }^{6}$

We can get a glimpse of this new world by looking at the islands of collaborating changemakers that already exist, for example, in the fluid interchanges of Silicon Valley (consider the free movement of people, the increase in open-sourcing, and the Valley's rapidly evolving support structures) or the Ashoka community of leading social and

\footnotetext{
${ }^{93}$ Start Empathy, Why, http://startempathy.org/why (last visited Apr. 9, 2015).

${ }^{94}$ Drayton, supra note 92 . Although "empathy" has become a controversial criteria for Supreme Court nominees, even the for-profit business world is increasingly recognizing it as a key to success. Compare Peter Baker, In Court Nominees, Is Obama Looking for Empathy by Another Name?, N.Y. Times (Apr. 25, 2010), http://www.nytimes.com/2010/04/26/us/politics/26memo. html, with Jason Boyers, Why Empathy is the Force that Moves Business Forward, ForBes (May 30, 2013, 1:26 PM), http://www.forbes.com/sites/ashoka/2013/05/30/why-empathy-is-the-forcethat-moves-business-forward/.

${ }^{95}$ See THRiLl MiLl, http://thrillmill.com/ (last visited Apr. 21, 2015).

${ }^{96}$ Drayton, supra note 89.
} 
allied business entrepreneurs (consider its breakthrough beyond solo entrepreneuring to "collaborative entrepreneurship"). ${ }^{97}$ including:

The IPI currently offers team-based "social entrepreneurship" courses,

- "Law, Entertainment and Social Enterprise," $" 98$ a practicum in which law students work closely with lawyers representing local social entertainment enterprises, such as public television stations and educational gaming companies; and

- Coulter Translational Research Partners Program II99 in partnership with the University of Pittsburgh Swanson School of Engineering and the University of Pittsburgh Innovation Institute's "From Benchtop to Bedside"100 course, in which law students work with scientists, physicians, bioengineers, and business students "to commercialize innovations and move basic research discoveries to the patient."

To expand these offerings, the IPI plans to work across disciplines, with Pitt's School of Social Work and School of Public Health, and across universities, with CMU's Heinz College, which "exists to improve the ability of public, not-for-profit, and private organizations to address the most difficult challenges facing society." Drawing on materials from Ashoka U, law students will learn that social entrepreneurship requires teams to work together to make reforms that are systems-changing, innovative, scalable, replicable, measurable, and sustainable. ${ }^{101}$

After completion of the team-based courses, the IPI and OPCD will work with law students to find internships with national and international lawyer social

${ }^{97} I d$.

${ }^{98}$ Law, Entertainment and Social Enterprise, supra note 43.

${ }^{99}$ See Coulter Translational Research Partners II Program, supra note 45. Each law student who participates on Coulter teams may elect to receive academic credit toward their law degree or a stipend supplied by the Coulter program itself.

${ }^{100}$ University of Pittsburgh Innovation Institute, From Benchtop to Bedside what every scientist needs to know, Course Syllabus, http://www.innovation.pitt.edu/sites/default/files/2015\%20B2B\% 20course\%20syllabus.pdf (last visited Apr. 10, 2015).

${ }^{101}$ Ashoka U., Changemaking 101: A Student Guide to Social Entrepreneurship, THE AlgERnON SYDNEY SulLIVAN FouND. 9, https://dl.dropboxusercontent.com/u/7252825/ashoka_studentkit_1215-12_final.pdf (last visited Apr. 10, 2015). UMKC Law School also offers several law and social entrepreneurship opportunities that provide models for law schools interested in training lawyer social entrepreneurs. See http://law.umkc.edu/pdfs/electives/social-entrepreneurshipventures-8757s.pdf; and http://law.umkc.edu/pdfs/electives/social-venture-creation-8915.pdf; http://bloch.umkc.edu/levitt/. 
entrepreneurs. Possible internships might include opportunities through Ashoka's "Law for All" initiative, which "works with social entrepreneurs and partners from the public, private, and social sectors to defend changemakers, encourage pro bono legal culture, and foster access to justice."102 Those internships may connect to other, existing Pitt Law resources, including funding from Pitt Law's "Pitt Legal Income Sharing Foundation" (PLISF), a student-run 501(c)(3) fundraising organization that awards grants to Pitt Law students pursuing unpaid, public interest summer internships, and Pitt Law's Nordenberg Fellowship program, which supports students studying abroad. ${ }^{103}$ Our goal is to weave social enterprise themes into the fabric of the law school's overall program.

In the third year of the program, IPI students will have the opportunity to explore the variety of career options open to lawyer social entrepreneurs through more advanced curricular and extracurricular offerings and further work in community settings. IPI-affiliated students, for example, are interning and working part-time in technology transfer offices both at the University of Pittsburgh and Carnegie Mellon University. The IPI aims to build the third year of its program by combining those opportunities with other, more novel ones with social entrepreneurship themes: Team-based projects identified during the students' second year may mature into entries into business plan competitions or grant applications for outside funding. For instance, two IPI students recently launched an award-winning social enterprise that will offer policy and legal services to Pittsburgh's urban agricultural community. ${ }^{104}$

To date, the IPI has worked with students succeeding along each of these pathways; our goal is to institutionalize each of them as part of the pilot program. We are also looking ahead to extending the IPI's impact beyond our students' graduation. We anticipate that students interested in solo law practice, for example, may transition into residency programs or a law practice incubator, currently in development at Pitt Law. We have already begun working under the IPI's auspices to advance the public presence and identity of recent graduates of Pitt Law who have initiated social entrepreneurship careers in Pittsburgh. ${ }^{105}$

\footnotetext{
102 Ashoka Innovators for the Public, Law for All Initiative, https://www.ashoka.org/lawforall (last visited Apr. 10, 2015).

103 The Nordenberg Fellowships, which cover up to $\$ 6,000$ in travel and living expenses, are funded by the Chancellor Mark A. Nordenberg University Professorship. See University of Pittsburgh, Pitt Law, Nordenberg Fellowships, http://law.pitt.edu/academics/cile/jd/competitions/ nord (last visited Apr. 10, 2015).

${ }^{104}$ See TRELLIS, http://www.trellispgh.com/ (last visited Apr. 10, 2015).

105 See Pittsburgh Humanities Festival: Rap Lyrics on Trial, http://aw.pitt.edu/events/newevent/pittsburgh-humanities-festival-rap-lyrics-trial (last visited Apr. 13, 2015) (describing the IPI's co-sponsorship of a public event organized in part by Legal Means, a social enterprise founded by a Pitt Law graduate that provides online tools to help indigent criminal defendants navigate the criminal justice system). Legal Means grew out of a class project for the IPI's Law, Entertainment and Social Enterprise course. InterSector, a Pittsburgh-based social enterprise accelerator, chose Legal Means as one of its portfolio of social enterprise startups. Social Enterprise, Social Enterprise: A New Type of Entrepreneurship, IDEA FoundRY,
} 
Our goal is to support and mentor law students as they progress toward professional independence. The IPI aims to collect, document, and institutionalize practices that exist in different ways and places across the existing law school program: Practicums may mature into internships. Internships may mature into paid employment.

The IPI and its pilot is itself, of course, a social enterprise startup, directed by two people - the authors - who think of themselves as social entrepreneurs as well as lawyers and educators. Our partners in the community ${ }^{106}$ and our partners at Pitt Law ${ }^{107}$ are likewise social entrepreneurs. As with all entrepreneurial ventures, we cannot anticipate whether, when, where, or how our vision and program will succeed. We plan to report back periodically, through the IPI's website, ${ }^{108}$ social media ${ }^{109}$ and published accounts regarding the evolution of our program and the progress of our graduates. As with all social entrepreneurs, and as guided by the experience and voice of Bill Drayton, we must measure our impact in terms of lives and communities changed.

\section{CONCLUSION}

Today's law school graduates need to be entrepreneurial to succeed. A focus on social entrepreneurship in legal education offers the prospect of bridging two worlds in need: law graduates in need of twenty-first century skills and abilities and twenty-first century communities in need of new solutions. As Bill Drayton notes,

Time and time again ... entrepreneurs with narrow objectives (including self-interest, shareholders' interests, or a religious or ideological end) pull the world astray .... Social entrepreneurs are the essential corrective force. ${ }^{110}$

In a world filled with injustice, lawyers have long served as an essential corrective force in courtrooms and board rooms, in non-profits and for-profits, and in public and private organizations. The time has come for law schools to prepare its students to play that corrective role as social entrepreneurs. The IPI is up for this challenge. As with all social entrepreneurs, we welcome fellow travelers.

http://ideafoundry.org/sectors/socialenterprise/ (last visited Apr. 9, 2015).

${ }^{106}$ Our community partners include those found elsewhere at the University of Pittsburgh and at Carnegie Mellon University, and at regional accelerators and incubators.

${ }^{107}$ Our Pitt Law partners include adjunct faculty helping us as teachers and student mentors, and graduates of the law school who share their time and wisdom in building a community of Pitt Law entrepreneurs and innovators.

${ }^{108}$ See InNOVATION PRACTICE INST., http://innovation-practice.org.

109 The Innovation Practice Institute tweets at @IPI Pgh.

${ }^{110}$ Drayton, supra note 89. 
